\title{
Assessment of the Water Quality of Chole River, Ethiopia using Benthic Macroinvertebrates and Selected Physicochemical Parameters
}

\author{
Alemayehu Negassa $^{1 *} \quad$ Gadise Silegna $^{2}$ \\ 1.Environmental Sciences Program, Departmentof Biology, Ambo University, Ethiopia \\ 2.Toke Kutaye Wreda Livestock Health Research Center, West Shoa, Ethiopia
}

\begin{abstract}
The water quality of Chole River was assessed based oninsitu measurements and laboratory analyses of water and benthic macroinvertebrates samples collected for three rounds from January - April, 2017 once every two months from three sites coded S1, S2 and S3 using standard procedures. Laboratory analyses of benthic macroinvertebrates samples yielded5712 specimens belonging to 26 families and 9 Orders. Percentage of sensitive taxa (Ephemeroptera, Plecoptera and Trichoptera) (\%EPT), Shannon diversity (H'), ETHbios score, Average Score Per Taxon and family richness decreased with increasing level of impacts from S1 through S3 to S2 in contrast to percentage of the tolerant Chironomidae (\%Chiro.), percentage of dominant taxon (\%DT) and Hilsonhoff's Family Biotic Index (H-FBI).Mean \%EPT was maximum at S1 (77.7\%), followed by S3 (16.4\%) and lowest at S2 (9.3\%) whereas red Chironomidae dominated at S2 (84.6\%) and S3 (91.8\%). Family richness was maximum at S1 (25) and minimum at S2 (22). The lowest dissolved oxygen $(4.29 \pm 1.85 \mathrm{mg} / \mathrm{l})$ and maximum total phosphorus $(6.09 \pm$ 0.09 ) were determined at S2indicating organic and detergent pollutions, respectively. Electrical conductivity (609 $\pm 169)$, Ammonium Nitrogen $(0.091 \pm 0.067 \mathrm{mg} / \mathrm{l})$, Nitrate nitrogen $\left(\mathrm{NO}_{3}{ }^{-} \mathrm{N}\right)$ and $(2.02 \pm 0.141 \mathrm{mg} / \mathrm{l})$ picked at $\mathrm{S} 3$ and remained relatively higher at $\mathrm{S} 2$. The heavy solid and liquid wastes loaded from Ambo University campus at S2 and common stressors at S3 including solid waste disposal, cattle watering, bathing, washing clothes and car washing might be responsible for the spatial variation in benthic macroinvertebrates indices/metrics and physicochemical parameterswhich indicateddeterioration in the water quality of Chole River at downstream sites. Keywords: Biomonitoring, Ethiopia, macroinvertebrates, physicochemical parameters, Water Quality
\end{abstract}

DOI: $10.7176 /$ JRDM/73-02

Publication date: February $28^{\text {th }} 2021$

\section{Introduction}

Currently, environmental pollution in general and pollution of flowing waters in particular has become a key focus of concern all over the world.Despite humanity's reliance on flowing waterrapid urbanization, industrialization and the expansion of agriculture have severely degraded thequality of rivers worldwide, diminishing their ability to provide valuable ecosystem services and driving species to extinction.Moreover, rivers in underdeveloped and developing countries are widely used as waste disposal sites for domestic and industrial wastes. Growinganthropogenic influenceson lotic environments has captured public interest because of the consequent problems associated with deterioration of water quality.

Anthropogenic activities may alter the physical, chemical, or biological processes associated with water resources and thus modify the resident community (Karr, 1991).Though physicochemical and bacteriological measurements commonly form the basis of river monitoring, they cannot reflect the integration of numerous environmental factors for their instantaneous nature ( $\mathrm{Li}$ et al., 2010). Because they focus on living organisms whose very existence represents the integration of conditions around them biological evaluations can diagnose chemical, physical, and biological impacts as well as their cumulative effects (Karr and Chu, 1997).The use of biological methods is based on the straightforward premise that living organisms are the ultimate indicators of environmental quality. When water no longer supports living things it will no longer support human affairs(Karr and Chu, 1999).Biomonitoring is a useful complementary approach to physicochemical monitoring and has proved invaluable in tracking water quality trends over time (Mandaville, 2002). Togetherphysicochemical and biological methods constitute the basis to a correct assessment of the quality of running waters (Li et al., 2010).

Amongst aquatic organisms, benthic macroinvertebrates have proved to be excellent indicators for the quality of freshwater stream habitats (Rosenberg and Resh, 1993; Mandavillae, 2002). They are widely used as bio-indicator in wadeable waters because they have generally limited mobility, quite easy to sample, well established sampling techniques, and there is a diversity of forms that ensures a wide range of sensitivities to changes in water quality (Hellawell, 1986; Abel, 1989). The use of macroinvertebrates as indicators of environmental change in Ethiopia dates back to the 1980s (e.g., Harrison and Hynes, 1988; TesfayeBerheet al., 1989), with a renewed interest in recent years following the advent of multimetric assessment methods (e. g., AbebeBeyene and WorkuLegesse, 2005; BayeSitotaw, 2006; AschalewLakew, 2007; BirenechAbay, 2007; Taffere Addis, 2008; Solomon Akalu, 2011;AschalewLakew, 2014; AschalewLakew, 2015; AschalewLakew and Moog, 2015;AlemayehuNegassa, 
2016; LamessaBerisaet al., 2019).

Chole River has long been used for a variety of purposes including source of public water supply, small scale irrigation, bathing, washing and livestock watering. Nevertheless, poor agricultural practices, overgrazing, deforestation, effluent dischargeand unregulated solid waste disposalwhich aregenerally widespread in the country remain serious problems in the catchment of Chole River with a potential of degrading its water quality. However, so far there is no research conducted on water quality of the river despite the multiplestressorsprevalentin its catchment. This study was conducted to assess the water quality of Chole River based on benthic macroinvertebratesindicators and selected physicochemical parameters.

\section{Materials and Methods \\ Description of the study area}

Chole River (Fig. 1) is one of the tributaries of Guder River located in the central highland of Ethiopia which originates near Wonchi Crater Lake and flows through Guder townat about $127 \mathrm{Kms}$ west of the capital, Addis Ababa. It is perennial and situated at $08057^{\prime} 397^{\prime \prime}-08058^{\prime} 657^{\prime \prime} \mathrm{N}, 037045^{\prime} 589^{\prime \prime}-037045^{\prime} 975^{\prime \prime} \mathrm{E}$ and an elevation of 1947-2818 meter above sea leveland constitutes important source of water for various development activities in Toke-kutaye district (Toke-kutayeworeda Agricultural and Rural Development Office, 2016). The main rainy months in the area range between June and September peaking in July and August. The dry months extend from October to May with some intermittent rain from February to April. The minimum and maximum air temperature ranged between 10 and $29^{\circ} \mathrm{C}$. The hottest months in the district range between March and May; while October to December constitutes the coldest months. Teff, maize, wheat, and barley are the major crops produced in the area.

\section{Selection of sampling sites}

Three sampling sites coded Site 1 (S1), Site 2 (S2) and Site 3 (S3) were selected along the river based onthe rapid bio assessment protocol (Barbour et al., 1999) considering vegetation cover, habitat types, substrate structure, agricultural activities, waste disposal, washing cloth, grazing and animal watering. Site 1 is located upstream withremnant riparian vegetation, someagricultural activities and sand mining. Site 2 was without vegetation cover except scattered eucalyptus trees along the river bank. It was receiving heavy solid and liquid wastes generated atAmbo UniversityGuder campus; and experiencing sand mining, grazing, cattle watering, washing clothes andbathing. Waste dumping, car washing, grazing, cattle watering and cloth washing were the common human activities noted at $\mathrm{S} 3$.

\section{In situ Measurements, Water Sampling and Analysis of Physico-chemical parameters}

Water quality parameters such as temperature, $\mathrm{pH}$, dissolved oxygen and conductivity were measured at the sampling sites in-situ using a portable multi-parameter probe before sampling the macroinvertebrates. Altitude, longitude and latitude were measured using global positioning system (GPS) at the sites.Composite water samples were collected in $2 \mathrm{~L}$ polyethylene bottles between $9 \mathrm{AM}$ to $12 \mathrm{AM}$, stored in icebox and transported to Chemistry Department Laboratory of Ambo University. In the laboratory, Nitrate (NO3-N), Ammonia+AmmoniumNitrogen and Total phosphorus (TP) were determined by Phenoldisulphonic Acid method using double beam UVSpectrophotometer (ELICO SL-160), using Spectrophotometer (ELICO SL-160) after distillation following Phenate method and by Ascorbic Acid Spectrophotometric method after digestion, respectively (APHA, 1998).

\section{Macroinvertebrates Sampling and Identification}

Benthic macroinvertebrate samples were collected using a standard hand net with frame width of $25 * 25 \mathrm{~cm}^{2}$ and mesh size $500 \mu \mathrm{m}$. A composite sample comprising 20 sampling units was taken from different habitat types. A sampling unit was a sample collected by positioning the net and disturbing the substrate in a quadratic area that equals the frame area of the net. Sampling began at the downstream end of the reach and proceeded upstream against the current. Megalithic stones were sampled by brushing their surfaces approximately equal to the size of the sampling net. Macrolithal stones were picked by hand and their surfaces were brushed to dislodge clingers and sessile organisms. Before preservation, quick identification of major taxa was performed on site as a quality assurance and samples were then preserved in $4 \%$ formalin in the field.

The preserved macroinvertebrate samples were transported and processed in the laboratory after carefully copying all information from the sample containers to the sample log sheet. A complete sample was passed through a set of sieves $(2000,1000,500$ and $250 \mu \mathrm{m}$ mesh size) in order to remove formalin and separate size classes of macroinvertebrates groups under tap water (AschalewLakew, 2014). Macroinvertebrates trapped in the coarse fraction of the sieve were identifiedusing naked eyes while organisms trapped in thesmaller fraction of the sieve were identified with the helpof dissecting microscope. Identification was performed to family level using South African Aquatic Invertebrates Identification key (Gerber and Gabriel, 2002). 


\section{Results}

Distribution and Abundance of Benthic Macroinvertebrates

A total of 5712 specimens of macroinvertebrates belonging to 26 Families and 9 Orders i. e. Diptera (3540), Trichoptera (935), Ephemeroptera (439), Oligochaeta (295), Bivalva (231), Gastropoda (188), Coleoptera (43), Hemiptera (22) and Odonata (19) were collected from the sampling sites along Chole River (Table 1). Distribution and abundance of the benthic macroinvertebrates varied among the sampling sites. Family richness was maximum at S1 (25) and minimum at S2 (22) in contrast to abundance which was highest at S2 (2772) and lowest at S1 (1032). The \%(EPT) decreased from S1 (77.7\%) through S3 (16.4\%) to S2 $(9.3 \%)$ with only a few numbers of Ephemeroptera and Trichoptera occurring at the lower reaches of S2 in contrast to \%(Chiro.) which increased from S1 (12\%) through S3 (46\%) to S2 (74\%).

H-FBI for the entire samples was 6.3 and increased from S1 (4.4) through S3 (7.1) to S2 (7.3) (Fig. 2). The minimum Shannon diversity index and evenness were recorded at S2 with maximum values determined at S3. ETHbios score decreased from S1 (95) through S3 (92) to S2 (81) and similar trend was noted in ETHbios-ASPT.

\section{Physicochemical Parameters}

The mean values and ranges of the physicochemical parameters determined at the sampling sites aregiven in Table 3. The temperature at the sampling sites along Chole River ranged from 14.5 to 27.5 whereas $\mathrm{pH}$ ranged from 8.15 to 8.91. The lowest and highest levels of mean dissolved oxygen were recorded at S2 (4.29 $\pm 1.85 \mathrm{mg} / \mathrm{l})$ and S1 $(7.18 \pm 0.91 \mathrm{mg} / \mathrm{l})$, respectively.Maximum and minimum conductivity were recorded at S3 (609 \pm 169$)$ and S1 $(496 \pm 160)$, respectively. Maximum values of both nitrate-nitrogen $(2.02 \pm 0.14 \mathrm{mg} / \mathrm{L})$ and total phosphorus $(6.09$ $\pm 0.09)$ were determined at S3.

\section{Discussions \\ Distribution and Abundance of Benthic Macroinvertebrates}

The spatial variation in distribution and abundance of benthic macroinvertebrates in Chole River appeared to be related to conditions of the habitats, influences of human induced pollutants and agricultural practices, as well as sensitivity/tolerance of the benthic fauna and in agreement with a report from Greater Akaki River by Solomon Akalu (2011). The conflicting trends in family richness and abundance noted at S1 and S2 are in accordance with the accepted view that as the upper part of river becomes pristine most fauna can inhabit it and there will be high competition, and can thus support fewer invertebrates than a site that is slightly impacted. BireneshAbay (2007) also reported that mild pollution has a tendency to increase total abundance which is in agreement with the present finding.

The decrease in the percentage of sensitive taxa (\%EPT) at S2 might be attributed to increased urbanization, effluent discharge from university campus and unregulated solid waste disposal. Previous reports (e. g., Baye Sitotaw, 2006, Birnesh Abay, 2007) indicated positive correlation between \%EPT and stream water quality which is in accordance with the present finding. The increase in \% Chiro.from S1 through S3 to S2 might indicate increased organic matter load and nutrient enrichement and supported with the accepted view that tolerant species become abundant in degraded streams and rivers (Birenesh Abay, 2007; Aschalew Lakew and Moog, 2015a).

H-FBI indicated good, poor and very poor water quality at S1, S3 and S2, respectively (Hilsenhoff, 1988). The H-FBI for the entire samples indicated substantial pollution and poor water quality which is in line with Baye Sitotaw (2006). Shannon diversity index and evenness indicated maximum deterioration at S2 since diversity is positively correlated with water quality. Walsh et al. (2001) reported low diversity of sensitive taxa in impacted streams which is in accordance with the present result. The maximum diversity index determined at S3 might be explained by the mild pollution which agrees well with Birenesh Abay (2007). ETHbios score and ASPT also indicated good water quality at S1 and deterioration at downstream sites mainly S2. Overall, the benthic macroinvertebrates indices/metrices determined varied among the sampling sites at Chole River in response to local stressors indicating increased water quality degradation at downstream sites.

\section{Physicochemical Parameters}

The spatial variation in the physicochemical parameters determined might be partly attributed to local stressors. The temperature at the sampling sites fell below the critical temperature for most macroinvertebrates i. e. $30^{\circ} \mathrm{C}$ (Welch, 1992). Chole River water was found to be alkaline at all sampling sites and comply with the EPA (2003) standard for surface water (6.0-9.0). The dissolved oxygen fell below the amount in unpolluted natural water $(10 \mathrm{mg} / \mathrm{L})$ and the level at S2 was below $(5 \mathrm{mg} / \mathrm{L})$ which is recommended for survival and normal functioning of biological communities (Chapman and Kimstach, 1996). The lowest dissolved oxygen determined at S2 might be attributed to the oxygen demanding wastes loaded except which the values recorded exceeded the values reported from other Ethiopian rivers including Guder River (Mulugeta Tilahun, 2012; $4.9 \pm 0.49 \mathrm{mg} / \mathrm{L}$ ) and Modjo River, (Baye Sitotaw, 2006; $6.1 \pm 4.01 \mathrm{mg} / \mathrm{L}$ ). The EC determined at the sampling sites fell in the range for freshwaters $(10-1000 \mu \mathrm{S} / \mathrm{cm})($ Chapman and Kimstach, 1996), and below the standard for surface waters $(1000 \mu \mathrm{S} / \mathrm{cm})(\mathrm{EPA}$, 
2003). The maximum EC determined at $\mathrm{S} 3$ is lower than the values reported from hitherto tested rivers in Ethiopia (e. g., Baye Sitotaw, 2006 and Seyoum et al. 2003)..

The maximum nitrate-nitrogen concentration determined fell below the limit for aquatic systems $(5 \mathrm{mg} / \mathrm{L})$ (Chapman and Kimstach, 1996) and in compliance with the EPA (2003) standard of $10 \mathrm{mg} / \mathrm{L}$. The increased level determined at S3 might be explained by enrichment through municipal wastes. The maximum total phosphorus determined at S3 might be explained by effluents containing phosphorus based chemicals including detergents discharged from Ambo University Campus as well as local washing and bathing. The phosphorous concentrations determined at the sampling sites along Chole River exceeded the concentrations in most natural waters $(0.006$ $0.02 \mathrm{mg} / \mathrm{l})$ and might again be explained by the detergent pollution.

There were significant correlations between the macroinvertebrates indices/metrices and most physicochemical parameters determined at the sampling sites along Chole River which is in accordance with Baye Sitotaw (2006) and Aschalew Lakew (2015a). The indices/metrics and physicochemical parameters determined together indicated pollution of Chole River at downstream sites in response to anthropogenic activities. This is in total agreement with Aschalew Lakew (2014) who correlated water quality deterioration with inadequate soil and water conservation measures, cattle grazing, deforestation, siltation, conversion of forest land into farmlands and effluent discharge.

\section{Conclusions}

The distribution and abundance of benthic macroinvertebrates and the physicochemical parameters determined varied among the sampling sites in response to local stressors. The indices/metrices and parameters determined indicated water quality deterioration at downstream sites mainly S2 with possible adverse effect on the valuable ecosystem services of the river and public health. Responsible authorities should take urgent ameliorative measures to stop further deterioration and restore the water quality of Chole River. Attempts to protect further deterioration and restore water quality of the river should involve regulating the waste water discharged to the river without treatment, promoting effective watershed management and introducing integrated solid waste management.

\section{Acknowledgments}

The authors would like to thank Austrian Development Cooperation Appear program for financial support and Ambo University for material support during field data collection and access to use laboratory facilities. The authors also extend sincere gratitude toother institutions and individuals who contributed to the project in one way or the other.

\section{References}

Abebe Beyene and Worku Legesse, (2005). Pollution status of river Borkena, Ethiopia sponsored By Jimma University and Ethiopian Science and Techenology Agency, (unpubilished)

Abel, P.D. (1989). Water Pollution Biology. John Wiley and Sons, New York, USA.p279.

Alemayehu Negassa (2016). Spatial and Temporal trends in the water quality of Huluka River, Ethiopia: an assessment using selected physicochemical and biological methods Thesis for ( $\mathrm{PhD})$, Addis Ababa University. Available on line at:etd.aau.edu.et/bitstream/123456789/13730/1/Alemayehu\%20Negassa\%20Emana

APHA (1998). Standard methods for the examination of water and waste water.20 $0^{\text {th }}$ edn, Washington, DC.

Aschalew Lakew (2007). Applicability of bioassessment methods using benthic macroinvertebrates to evaluate the ecological status of highland streams and rivers in Ethiopia Msc thesis, UNESCO-IHE Delft, The Netherlands.

Aschalew Lakew(2014). Development of biological monitoring systems using benthic invertebrates to assess the ecological status of central and southeast highland rivers of Ethiopia. PhD Thesis, University of Natural Resources and Life Sciences at Vienna, Austria: $163 \mathrm{pp}$.

Aschalew Lakew (2015a). Assessing Anthropogenic impacts using benthic macroinvertebrates as bio-indicator in central highland streams of Ethiopia. Ethiop.J.Env. Stud.\& Man., 8(1):45-26.

Aschalew Lakew \& Moog, O. (2015a). A multimetric index based on benthic macroinvertebrates for assessing the ecological status of streams and rivers in central and southeast highlands of Ethiopia. Hydrobiologia,751:229 -242 .

Bae, J. Y., Kil, K. H. \& Bae, S. K. (2005).Benthic Macroinvertbrates for uses in stream Biomonitoring and Restoration.KSCE J.Civ. Eng., 9(1):55-65.

Barbour, M.T., Gerritsen, J., Snyder, B.D. \& Stribling, J.B. (1999). Rapid Bioassessment Protocols for Use in Streams and Wadeable Rivers: Periphyton, Benthic Macroinvertebrates and Fish, 2nd edn. EPA 841-B-99002.U.S. Environmental Protection Agency, Office of Water, Washington, DC.

Baye Sitotaw (2006). Macroinvertebrates assemblage structure in relation to environmental degradation in some Ethiopian rivers. M.Sc. Thesis, School of Graduate Studies. Addis Ababa University, Addis Ababa.

Birenech Abay (2007). Assessment of Downstream pollution profiles of Awassa Textile Factory Effluent along 
Tikurwuha River Using physico-chemical and Macroinvertebrate Indicators, Ethiopia.

Chapman, D. \& Kimstach, V. (1996).Selection of Water Quality Variables.In; Water Quality Assessments.A guide to the use of biota, sediments and water in environmental monitoring, pp. 243-318 (Ed.Chapman, D.), Cambridge.

Environmental Protection Authority (EPA) (2003). Guideline Ambient Environment Standard for Ethiopia, 101pp. Prepared by Environmental Protection Authority in collaboration with the United Nations Industrial Development Organization, Addis Ababa.

Gerber, A.M \& Gabriel, J.M (2002). Institute for water quality studies department of water Affairs and Forestry version 2, April 2002.

Harrison, A. D. \& Hynes, H. B. N. (1988). Benthic fauna of Ethiopian mountain streams and rivers. Archiv fur Hydrob. Suppl., 81: 1-36.

Hellawell, J. M. (1986). Biological Indicators of fresh water pollution Environmental Management. Elsevier, London, pp.518.

Hill, H. B., Stevenson, J. R., Pan, Y., Herlihy, T. A., Kaufmann, R. P. \& Johnson, B. C. (2001). Comparison of correlations between environmental characteristics and stream diatom assemblages characterized at genus and species levels. J. N. Am.Benthol. Soc.,20(2):299-310.

Hilsenhoff, W.L. (1988). Rapid field assessment of organic pollution with a family-level biotic index. J. N. Am. Benthol. Soc., 7 (1): 65-68.

Karr J. R. \& Dudley, R. D. (1981).Ecological Perspective on Water Quality Goals.Environ. Man., 5:55-68.

Karr, J. R. (1991). Biological Integrity: A Long-Neglected Aspect of Water Resource Management. Ecol. Appl., 1(1): 66-84

Karr, J. R., \& Chu, E. W. (1997).Biological Monitoring and Assessment: Using Multimetric Indices Effectively. EPA 235-R97-001.University of Washington, Seattle.

Karr, J. R. \& Chu, E. W. (1999). Restoring life in running water: better biological monitoring. Island Press, Washington, DC.

Lammessa Berisa, Aschalew Lakew \& Alemayehu Negassa (2019). Assessment of the Ecological Health Status of River Berga Using Benthic Macroinvertebrates as Bioindicators, Ethiopia.N. Am. Acad. R., 2(6): 09-17.

Li, L., Zheng, B. \& Liu, L. (2010).Biomonitoring and Bioindicators used for River Ecosystems: Definitions, Approaches and Trends. Proc.Env.Sci., 2:1540-1524.

Mandaville, S. M. (2002). Benthic Macroinvertebrates in Freshwaters- Taxa Tolerance Values, Metrics, and Protocols. New York: Research Scientist III, Division of Water New York State Department of Environmental Conservation.

Miserendrio, M. L. (2001). Macroinvertebrate assemblages in Andean Patagonian Rivers and streams: Environmental relationships. Hydrobiologia, 444:14-158.

Mulugeta Tilahun (2012). Study on abundance and distribution of benthic macroinvertebrates in river Guder, Ethiopia. M.Sc. Thesis. School of Graduate studies, Ambo University.

Rosenberg, D.M. \& V.R. Resh (1993). Introduction to freshwater biomonitoring and benthic

Macroinvertebrates. Pp. 1-9 in: Rosenberg, D.M. (Ed.), Freshwater Biomonitoring and Benthic Macroinvertebrates. Kluwer, London.

Seyoum Leta, Fassil Asefa \& Gunnel (2003). Characterization of Tannery wastewater and assessment of downstream pollution profiles along Mojo River, Ethiopia. J. Biol. Sci., 2(2): 157-168.

Solomon Akalu, Seyoum Mengistou \& Seyoum Leta (2011).Assessing Human Impacts on the Greater Akaki River, Ethiopia using Macroinvertebrates.SINET: Ethiop. J. Sci., 34(2):89-98.

Taffere Addis (2008). Comparative study of macroinvertebrates and diatoms as Bioindicators of River Water Quality in Addis Ababa.M.sc thesis school of Graduate Studies, Addis Ababa University.

Tesfaye Berhe (1988). The degradation of the Abo-Kebena River in Addis Ababa. Ethiopia. M.Sc. Thesis, School of Graduates Studies, Addis Ababa University.

Toke-kutaye Woreda ARDO (2016). Toke-kutayeWoreda Agricultural and Rural Development Office Annual Report.

Welch, E.B. (1992): Ecological Effects of Waste water Applied Limnology and Pollutant Effects, $2^{\text {nd }}$ edition. London: Chapman and Hall.

Walsh, C.J., Sharpe, A. Breen, P.F. \& Sonneman J.A. (2001).Effects of urbanization on streams of the Melbourne region, Victoria, Australia.Freshw. Biol., 46: 535-551. 


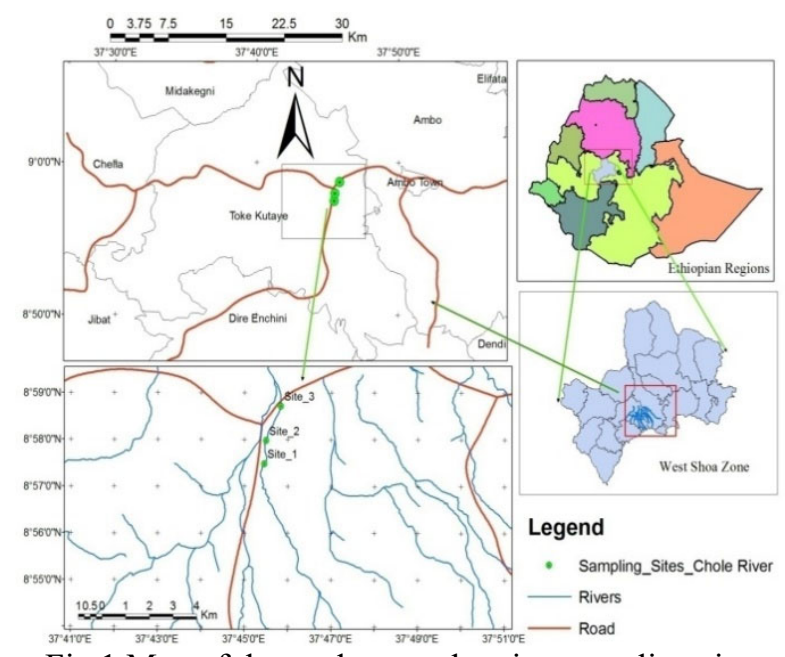

Fig.1 Map of the study area showing sampling sites

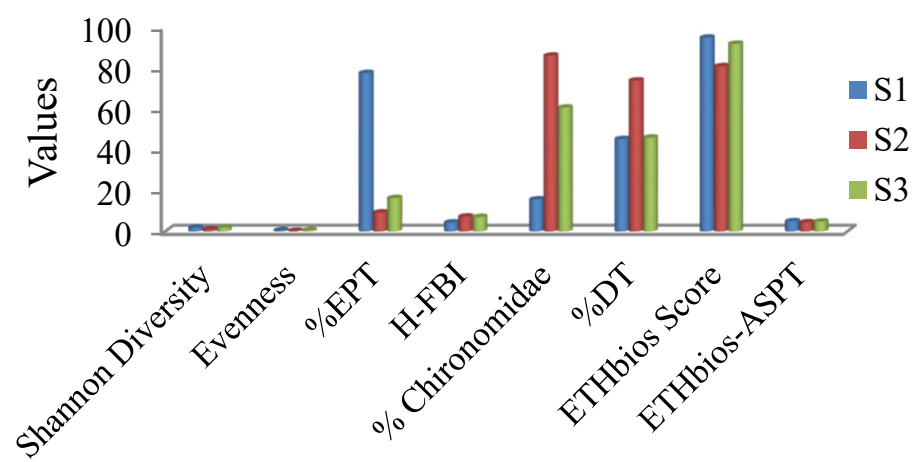

Macroinvertebrate Indices/Metrices

Fig. 2 Macroinvertebrate Indices/metrics determined 
Table 1. Distribution and abundances of benthic macroinvertebrates at the sampling sites

\begin{tabular}{llccc}
\hline \multirow{2}{*}{ Order } & & \multicolumn{3}{c}{ Number of Individuals } \\
\cline { 2 - 5 } GASTROPODA & Family & Ste 1 & Site 2 & Site 3 \\
\multirow{3}{*}{ BIVALVA } & Physidae & 3 & 16 & 109 \\
OLIGOCHAETA & Planorbidae & 3 & 10 & 45 \\
EPHEMEROPTERA & Ancylidae & 2 & 0 & 0 \\
& Sphaeriidae & 0 & 0 & 231 \\
ODONATA & Baetidae & 23 & 45 & 227 \\
HEMIPTERA & Caenidae & 133 & 65 & 98 \\
& Heptagenidae & 25 & 38 & 51 \\
TRICHOPTERA & Aeshnidae & 20 & 0 & 9 \\
& Libellulidae & 5 & 2 & 3 \\
COLEOPTERA & Naucoride & 5 & 1 & 3 \\
& Gerridae & 4 & 2 & 2 \\
Corixidae & 3 & 1 & 5 \\
DIPTERA & Hydropsychidae & 4 & 1 & 0 \\
& psychomyiidae & 467 & 56 & 18 \\
& Polycentropodidae & 151 & 98 & 132 \\
& Gyrinidae & 6 & 2 & 5 \\
& Dytiscidae & 4 & 2 & 3 \\
Total Number of Families & Elmidae & 6 & 3 & 4 \\
Total Number of Individuals & Hydrophilidae & 4 & 4 & 2 \\
\hline & Chironomidae & 5 & 4 & 2 \\
& Tipulidae & 124 & 2050 & 880 \\
& Simuliidae & 13 & 10 & 9 \\
& Psychodidae & 12 & 348 & 63 \\
& Muscidae & 4 & 4 & 1 \\
& Tabanidae & 4 & 9 & 5 \\
& 26 & 2 & 1 & 1 \\
& 5712 & 25 & 22 & 24 \\
& & 1032 & 2772 & 1908 \\
\hline
\end{tabular}

Table 2. Physicochemical parameters determined at the sampling sites

\begin{tabular}{llll}
\hline & \multicolumn{3}{c}{ Sampling sites } \\
\cline { 2 - 4 } Parameter & \multicolumn{1}{c}{ S1 } & \multicolumn{1}{c}{ S2 } & \multicolumn{1}{c}{ S3 } \\
\hline $\mathbf{p H}$ & $8.52 \pm 0.38(8.15-8.91)$ & $8.3 \pm 0.19(8.12-8.5)$ & $8.62 \pm 0.2(8.39-8.77)$ \\
$\mathbf{E C}(\boldsymbol{\mu} \mathbf{S} / \mathbf{c m})$ & $496 \pm 160(319-630)$ & $565 \pm 194(355-736)$ & $609 \pm 169(449-785)$ \\
DO $(\mathbf{m g} / \mathbf{l})$ & $7.18 \pm 0.91(6.27-8.09)$ & $4.29 \pm 1.85(4.21-6.18)$ & $7.17 \pm 1.38(5.6-8.19)$ \\
DO $(\%)$ & $108 \pm 26.7(88.9-138.2)$ & $63.5 \pm 27.4(40.9-94)$ & $112 \pm 27.3(85.5-140)$ \\
$\mathbf{H}_{\mathbf{2}} \mathbf{O} \mathbf{T e m p}\left({ }^{(} \mathbf{C}\right)$ & $22 \pm 6.73(14.5-27.5)$ & $23 \pm 4.58(18-27)$ & $24.6 \pm 2.71(22-27.4)$ \\
Air Temp $\left({ }^{0} \mathbf{C}\right)$ & $23.3 \pm 6.43(16-28)$ & $23.8 \pm 4.37(19-27.5)$ & $25.3 \pm 2.41(23-27.8)$ \\
TP $(\mathbf{m g} / \mathbf{l})$ & $0.28 \pm 0.09(0.2-0.37)$ & $6.09 \pm 0.09(6-6.18)$ & $0.28 \pm 0.15(0.16-0.45)$ \\
$\mathbf{N H}_{4}{ }^{+} \mathbf{N}$ & $0.014 \pm 0.006(0.01-0.02)$ & $0.016 \pm 0.012(0.009-0.03)$ & $0.091 \pm 0.067(0.013-0.135)$ \\
$\mathbf{N O}_{3}-\mathbf{N}$ & $0.324 \pm 0.04(0.291-0.37)$ & $0.941 \pm 0.076(0.86-1.012)$ & $2.02 \pm 0.141(1.86-2.125)$ \\
\hline
\end{tabular}

